\title{
Malfunction Only (No AE) Report
}

National Cancer Institute

\section{Source}

National Cancer Institute. Malfunction Only (No AE) Report. NCI Thesaurus. Code C156385.

A report of a device malfunction that does not include an adverse event. 